\title{
Follicular Dendritic Cell Tumor of the Liver: A Clinicopathologic and Epstein-Barr Virus Study of Two Cases
}

\author{
Tse-Ching Chen, M.D., Tseng-tong Kuo, M.D., Ph.D., Kwai-Fong Ng, M.D. \\ Department of Pathology, Chang Gung Memorial Hospital, Chang Gung University School of Medicine, \\ Kwei San, Tao Yuan, Taiwan
}

\begin{abstract}
Two cases of hepatic follicular dendritic cell (FDC) tumor are described. Both patients were female, aged 57 and 51 years. They presented with epigastralgia or abdominal fullness and weight loss. The first patient refused surgical resection. She developed progressive polyclonal gammopathy and then bilateral purpura over the legs. Skin biopsy revealed leukocytoclastic vasculitis with granular vascular deposits of IgA and $\mathrm{C}_{3}$. The second patient had marked peripheral blood and tissue eosinophilia. The histological diagnosis was confirmed by positive staining for CD21 and CD23. The stromal lymphocytes were predominantly composed of CD3(+) and CD8(+) cells. In situ hybridization for EBER showed a positive nuclear signal in tumor cells but not in inflammatory cells. Polymerase chain reaction amplification for Exon 3 of the latent membrane protein-1 (LMP-1) gene showed a characteristic 30-bp deletion between nucleotides 168282 and 168253 , corresponding to the B95-8 sequence. The unique clinicopathological features of our cases have not been reported for FDC tumors before. The clinical significance of the 30-bp deletion in Exon 3 of the LMP-1 gene in FDC tumor of the liver warrants further investigation.
\end{abstract}

KEY WORDS: Eosinophilia, Epstein-Barr virus, Follicular dendritic cell, Latent membrane protein-1 gene, Liver, Leukocytoclastic vasculitis.

Mod Pathol 2001;14(4):354-360

Copyright $\odot 2001$ by The United States and Canadian Academy of Pathology, Inc.

VOL. 14, NO. 4, P. 354, 2001 Printed in the U.S.A.

Date of acceptance: September 8, 2000.

This work was supported by grants from the National Science Council of the Republic of China (NSC89-2314-B-182-011) and the Chang Gung Medical Research Fund (NMRP509 and CMRP799).

Address reprint requests to: Tse-Ching Chen, M.D., Department of Pathology, Chang Gung Memorial Hospital, Kwei San, Tao Yuan, Taiwan; e-mail: ctc323@mail.cgu.edu.tw; fax: 886-3-3280147.
The follicular dendritic cell (FDC) tumor was first reported by Monde et al. (1) in 1986. Since then, approximately 50 cases of FDC tumor have been reported (1-12). In most of these cases, the sites affected were the lymph nodes. Extranodal cases were uncommon. Approximately $12 \%$ of FDC tumors were demonstrated to contain the EpsteinBarr virus (EBV) sequence (7). Therefore, EBV may play a role in the pathogenesis of the FDC tumor. In this report, we describe two FDC tumors of the liver with unique clinical features and a unique EBV subtype.

\section{MATERIALS AND METHODS}

Two cases of hepatic FDC tumor were retrieved from the surgical pathology files of Chang Gung Memorial Hospital from the period 1996 to 1999. Formalin-fixed and paraffin-embedded tissues were used for histopathologic, immunohistochemical, and in situ hybridization studies. The immunohistochemical studies were performed using the avidin-biotin-peroxidase complex method. A panel of antibodies was used, and the antibodies are listed in Table 1. A fresh skin biopsy specimen (Case 1) was also subjected to direct immunofluorescence studies for IgG, IgM, IgA, $\mathrm{C}_{3}$, and $\mathrm{C}_{4}$. EBV-encoded nuclear RNA (EBER) in situ hybridization studies were performed with a DAKO fluoresceinconjugated EBV (EBER) PNA probe (complementary to two nuclear EBER RNAs encoded by EBV; DAKO A/S, Glostrup, Denmark) on 5- $\mu \mathrm{m}$-thick, deparaffinized, and proteinase $\mathrm{K}$-pretreated tissues for 1.5 hour at $55^{\circ} \mathrm{C}$. After washing, the reaction was detected by the DAKO PNA ISH detection Kit (DAKO A/S).

\section{Latent Membrane Protein-1 Gene Study}

Fresh tumor tissue obtained from Case 2 was frozen at $-80^{\circ} \mathrm{C}$ until analyzed. High-molecular weight DNA was purified by phenol/chloroform ex- 
TABLE 1. Antibodies Used in this Study

\begin{tabular}{llrc}
\hline \multicolumn{1}{c}{ Antibody } & \multicolumn{1}{c}{ Source } & Dilution & Pretreatment \\
\hline CD21 & DAKO & $1: 50$ & TP \\
CD23 & The Binding Site & $1: 50$ & PC \\
CD35 & DAKO & $1: 20$ & TP \\
CD3 & DAKO & $1: 800$ & TP \\
CD20 & DAKO & $1: 1600$ & PC \\
CD4 & Novocastra & $1: 10$ & PC \\
CD8 & DAKO & $1: 100$ & PC \\
HHF-35 & DAKO & $1: 400$ & TP \\
$\kappa$ light chain & DAKO & $1: 1000$ & TP \\
$\lambda$ light chain & DAKO & $1: 1000$ & TP
\end{tabular}

PC, pressure cooking in EDTA for 2 minutes or in citrate buffer for 3 minutes; TP, trypsinization for 20 minutes.

traction, followed by ethanol precipitation. DNA pellets were resuspended in distilled water. To examine the 30-bp deletion in Exon 3 of the latent membrane protein-1 (LMP-1) gene, a set of primers, 9/11 described by Knecht et al. (13), were used. The amplification reaction mixture contained 10 mm Tris HCL ( $\mathrm{pH} 7.5$ ), $50 \mathrm{~mm}$ sodium chloride, 10 mM magnesium chloride, $1.5 \mathrm{~mm}$ dNTP, 2 primers $(0.2 \mu \mathrm{M}$ each), and 2.5 units of Taq DNA polymerase. DNA preparations from B95-8 cells and pT7 strain were used as controls. The amplification cycle included 1 minute of DNA denaturation at $95^{\circ} \mathrm{C}$ followed by 1 minute of annealing at $55^{\circ} \mathrm{C}$ and 1 minute of DNA extension at $72^{\circ} \mathrm{C}$. The amplification was repeated for 30 cycles. After the reaction, one tenth of the reaction mixture was fractioned electrophoretically in $6 \%$ polyacrylamide gel and visually inspected under ultraviolet light for the presence of DNA bands of appropriate size after ethidium bromide staining. The PCR products were directly analyzed on the gel by size difference.

DNA sequencing for the PCR products of Exon 3 of the LMP-1 gene was carried out using an ABI PRISM dRhodamine terminator cycle-sequencing ready reaction kit. Reaction products were analyzed on the ABI PRISM 377 DNA sequencer using ABI PRISM sequencing 3.0 software.

\section{RESULTS}

\section{Clinical Histories}

\section{Case 1}

A 57-year-old woman was admitted to Chang Gung Memorial Hospital because of intermittent epigastralgia of 2 weeks' duration. A $9.5 \times 7.6 \mathrm{~cm}$ hepatic left lobe tumor was found after a series of imaging studies. Laboratory investigations showed a mild anemia and slightly increased serum globulin. She was positive for serum hepatitis B surface antigen (HBsAg) and negative for anti-hepatitis $\mathrm{C}$ virus (HCV) antibody. Serum $\alpha$-fetoprotein was 6 $\mathrm{ng} / \mathrm{mL}$. Initial protein electrophoresis only showed slightly increased $\alpha 1$-globulin. The patient refused surgical resection. During follow-up, serum $\gamma$ globulin began to increase (from 1.5 to $2.6 \mathrm{gm} \%$ ), and repeat protein electrophoresis showed a chronic inflammation pattern with a polyclonal increase of $\gamma$-globulin. Later, she developed lower limb purpura bilaterally. A skin biopsy was taken. Immunological investigations revealed the following levels: serum IgA, 578 mg\% (normal, 74.7-373.5); $\mathrm{C}_{3}, 8.4$ mg\% (normal, 82.5-180); and $\mathrm{C}_{4}, 13.3 \mathrm{mg} \%$ (normal, 18.2-45.5). Antinuclear antibody was negative. The liver also progressively enlarged to a maximum span of $15 \mathrm{~cm}$ in a 3-year period. No metastases were found. The patient is now receiving steroid treatment.

\section{Case 2}

A 51-year-old Taiwanese woman presented with abdominal fullness and weight loss of $6 \mathrm{~kg}$ within 3 months. Abdominal ultrasound revealed a mixed echoic mass in the left hepatic lobe. She had no fever. Liver function tests were within normal ranges. Hematological investigations produced the following results: hemoglobin, $10.7 \mathrm{~g} \%$, white blood cell, $12.3 \times 10^{9} / \mathrm{L}$ with $46 \%$ polymorphs, $38 \%$ eosinophils, $10 \%$ lymphocytes, $4 \%$ monocytes, and $1 \%$ basophils. Serum HBsAg and anti-HCV antibody were negative. Serum $\alpha$-fetoprotein was less than 3 $\mathrm{ng} / \mathrm{mL}$ (normal, less than 3 ), and carcinoembryonic antigen was $0.78 \mathrm{ng} / \mathrm{mL}$ (normal, less than 5). An abdominal computed tomographic scan showed a $15 \times 12 \times 10$-cm heterogenous mass in the right hepatic lobe. An angiographic study showed that the tumor was hypervascular. She underwent left lobectomy. Her blood eosinophil count returned to the normal range, and she was well, with no evidence of disease 1 year after the operation.

\section{Pathologic Findings}

The liver biopsy specimen from Patient 1 measured $1.7 \mathrm{~cm}$ in length. Microscopically, it showed a spindle cell tumor arranged in irregular pattern or in short fascicles with dense infiltrates of small lymphocytes and plasma cells (Fig. 1). The spindle cells had vesicular nuclei and small basophilic nucleoli with indistinct cell borders. The skin biopsy from the leg of Patient 1 showed thickened dermal vessels with fibrinoid necrosis and surrounded by mononuclear cells, neutrophils, and eosinophils undergoing karyorrhexis (Fig. 2). Extravasated red blood cells were diffusely present.

The resected liver from Patient 2 measured $17 \times$ $17 \times 9 \mathrm{~cm}$ and weighed $1150 \mathrm{~g}$. There was a wellcircumscribed but unencapsulated tumor measuring $12 \times 11 \times 9 \mathrm{~cm}$. It was tan colored and soft with areas of necrosis and hemorrhage (Fig. 3). No daughter nodules were present. Histologic features were generally similar to that observed in Patient 1. 


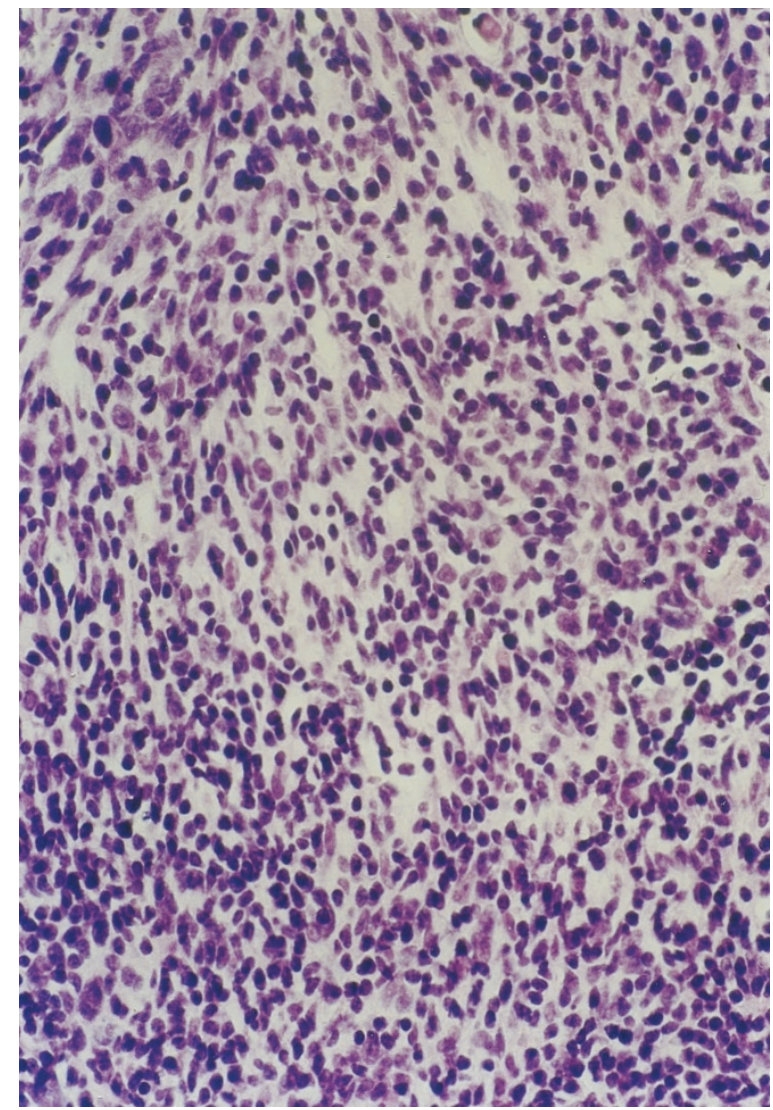

FIGURE 1. Liver biopsy (Patient 1) showing a spindle cell tumor with dense infiltrates of plasma cells and lymphocytes.

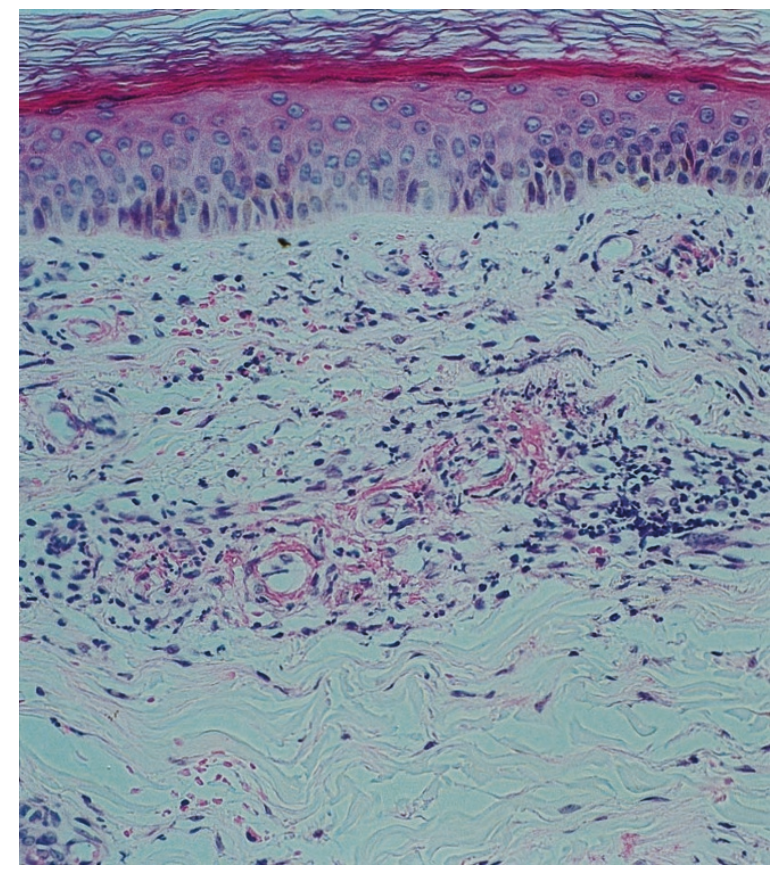

FIGURE 2. Skin biopsy (Patient 1) showing thickened dermal vessels with fibrinoid necrosis and surrounded by mononuclear cells, neutrophils, and eosinophils undergoing karyorrhexis.

In addition, the tumor cells were arranged in storiform, whorled, and interlacing fascicle patterns

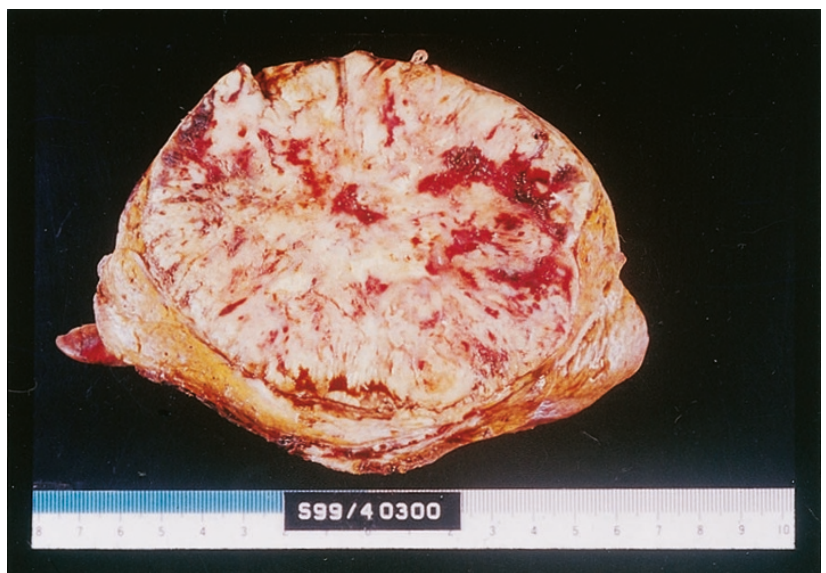

FIGURE 3. A well-circumscribed but unencapsulated tumor in the liver with areas of necrosis and hemorrhage (Patient 2).

(Fig. 4). A few multinucleated giant cells were observed. There was no obvious cellular atypia. Mitotic figures averaged 1 per 10 high-power fields. There was multifocal geographic necrosis and hemorrhage. The non-tumor area contained scattered infiltrates of neoplastic FDCs in portal tracts and hepatic lobules.

\section{Immunohistochemical Study}

The tumor cells in both cases were positive for CD21 (Fig. 5), CD23, and HHF-35 (muscle-specific actin). They were negative for CD35. The stromal small lymphocytes were predominantly composed of CD3 $(+) \mathrm{T}$ cells, among which CD8 $(+)$ T cells clearly outnumbered CD4 (+) T cells (Fig. 6). The plasma cells were polyclonal as evidenced by a mixture of both $\kappa(+)$ and $\lambda(+)$ cells.

\section{EBER In Situ Hybridization}

The spindle cells in both cases showed positive nuclear EBER signals (Fig. 7), whereas the inflammatory cells in the background were negative.

\section{LMP-1 Gene Study}

The presence of the EBV genome was confirmed by polymerase chain reaction with the LMP-1 gene in Patient 2. In addition, the LMP-1 gene also had a 30-bp deletion in Exon 3 as compared with the products from B95-8 cells (Fig. 8). We further sequenced the PCR product and confirmed a 30-bp deletion between nucleotides 168282 and 168253 (corresponding to the B95-8 sequence). There were also point mutations at positions $168367(\mathrm{C} \rightarrow \mathrm{A})$, $168320 \quad(A \rightarrow G), \quad 168308 \quad(T \rightarrow C), 168295 \quad(A \rightarrow T)$, $168285(\mathrm{C} \rightarrow \mathrm{G})$, and $168225(\mathrm{~T} \rightarrow \mathrm{A})$.

\section{DISCUSSION}

FDC tumor is a rare disease. Approximately two thirds of documented cases occurred in the lymph 

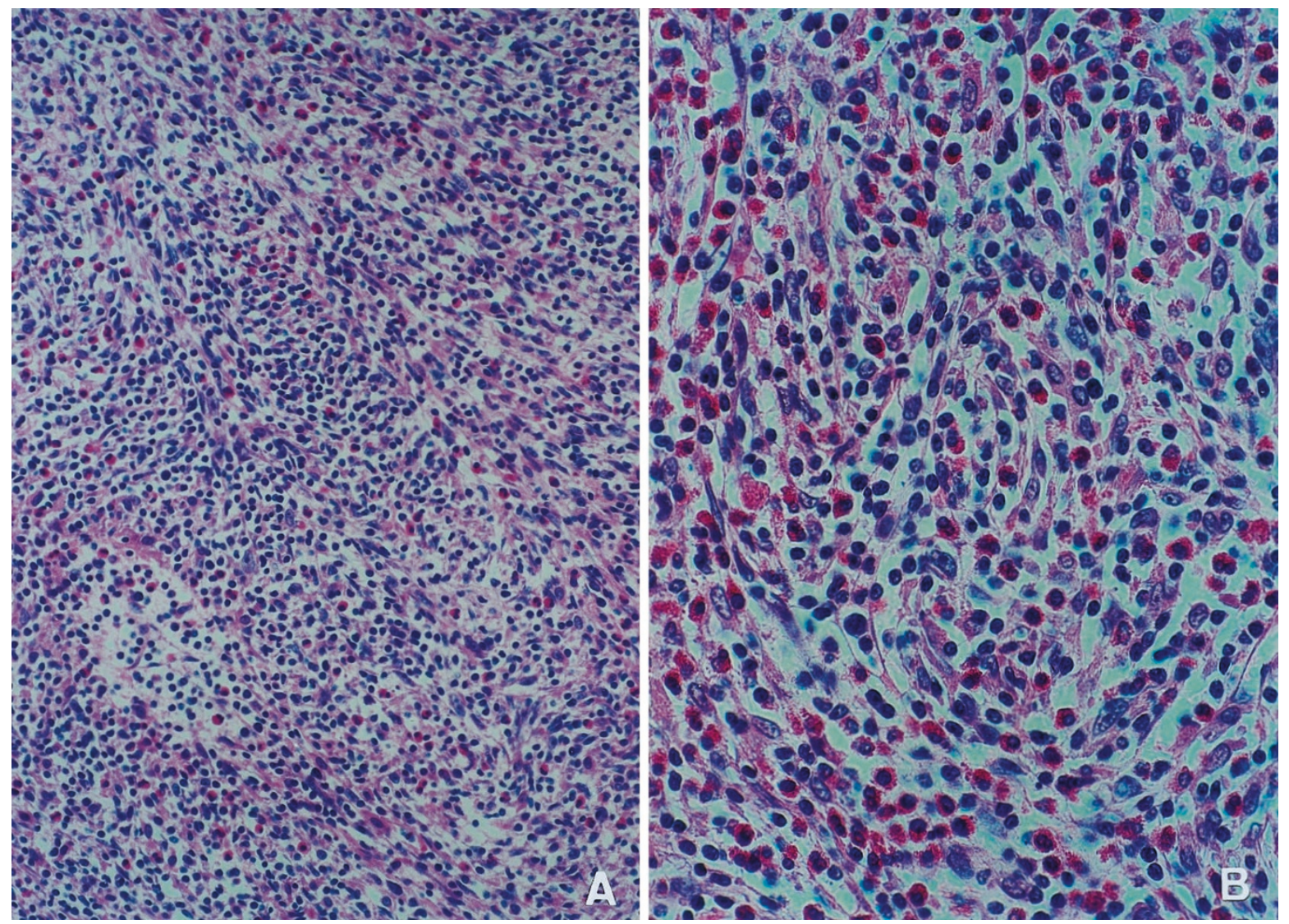

FIGURE 4. The spindle tumor cells showed vesicular nuclei, small nucleoli, and indistinct cytoplasmic borders. They were arranged in fascicles (A) and whorled (B) patterns. Note the marked eosinophilic infiltration (Patient 2).

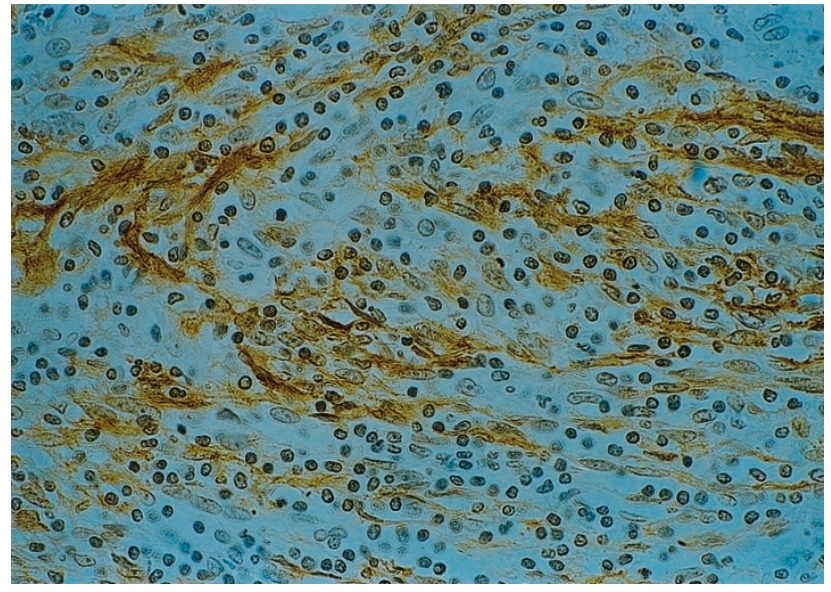

FIGURE 5. The spindle cells were immunoreactive with CD21.

nodes (6). It has also been reported in extranodal sites, including the palate (2), tonsils (5-7), pharynx (6), intraabdominal soft tissue (mesentery and mesocolon; 3,4$)$, ampulla of Vater (12), pancreas (7), spleen (8), and liver (10-12). To our knowledge, three cases have previously been reported with liver involvement (Table $1 ; 8-10$ ). All patients were female, aged from 35 to 57 years. The presenting symptoms were nonspecific, including abdominal fullness, epigastralgia, low-grade fever, weight loss,

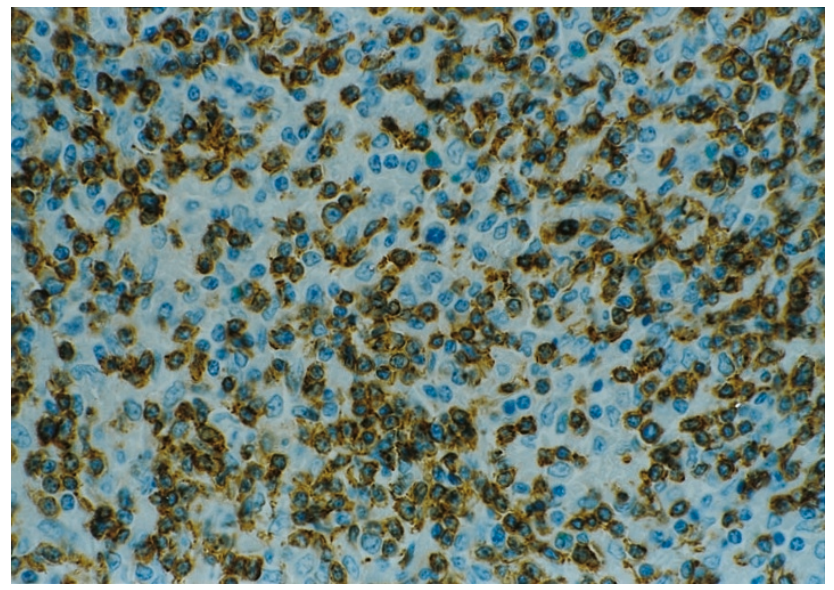

FIGURE 6. The small lymphocytes in the background were predominantly CD8 (+) cells.

slight anemia, and hypergammaglobulinemia. Of these three reported cases, in two cases, the tumors were located in the right lobe, and in the third case, the left lobe. Tumor size usually measured more than $10 \mathrm{~cm}$ in greatest diameter. Over the past 3 years, we have encountered two cases in Taiwan. As reported previously, the hepatic tumors were bulky and occurred in older females. In both cases, the tumors were located in the left lobe. The first pa- 


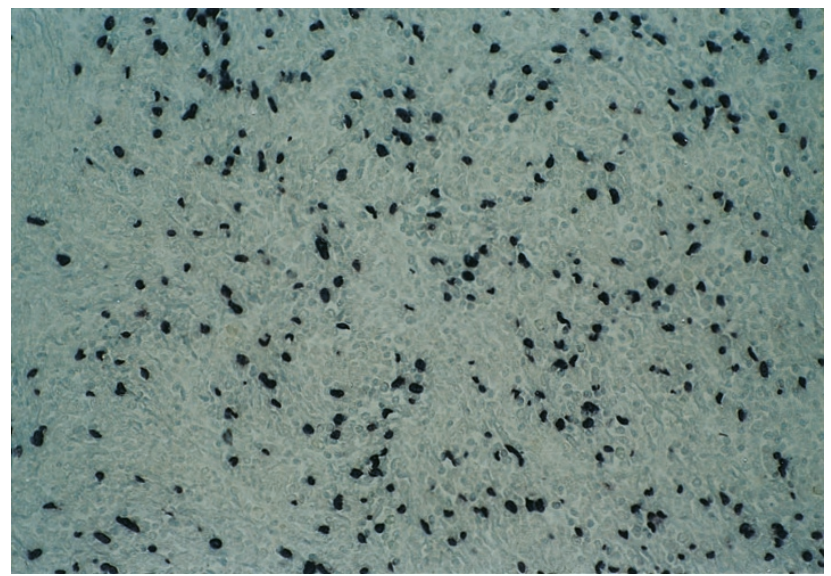

FIGURE 7. Positive Epstein-Barr virus-encoded nuclear RNA signal was confined to the nuclei of neoplastic follicular dendritic cells.

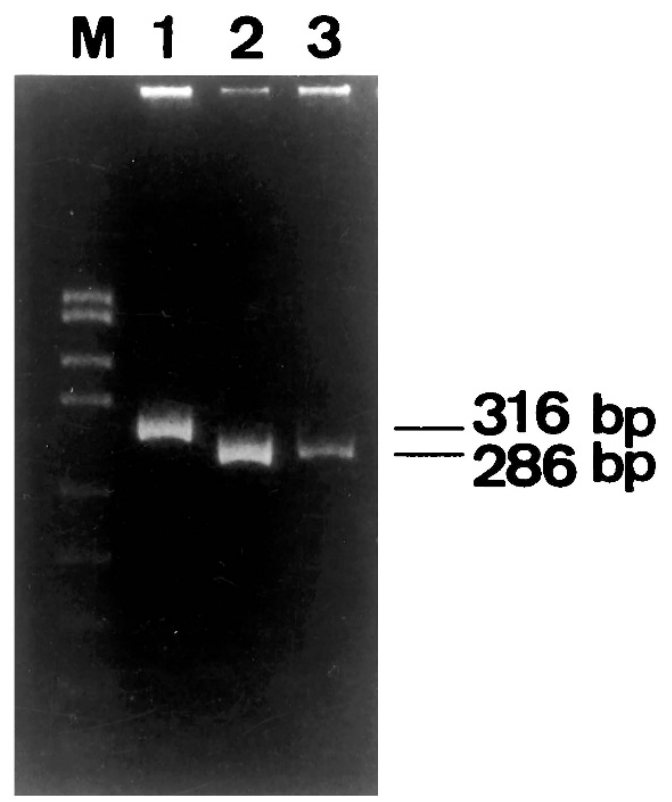

FIGURE 8. Analysis of PCR products from Exon 3 of the latent membrane protein-1 gene. DNA fragments of $316 \mathrm{bp}$ and $286 \mathrm{bp}$ were generated with the B95-8 strain (Lane 1) and plasmid pT7 (Lane 2). Case 2 (Lane 3) had a 286-bp product with a characteristic 30-bp deletion as compared with the B95-8 strain and was the same as that from plasmid pT7.

tient refused surgical resection, which gave us the opportunity to observe the natural course of a hepatic FDC tumor. Over a 3-year follow-up period, hypergammaglobulinemia occurred insidiously, with the level progressively increasing but remaining polyclonal. The patient then developed lowerlimb leukocytoclastic vasculitis bilaterally with granular IgA and $\mathrm{C}_{3}$ deposits. Marked eosinophilia was found in the second patient's peripheral blood. The inflammatory cells in FDC tumor also demonstrated marked eosinophilic infiltration in addition to small lymphocytes and plasma cells. The peripheral blood eosinophil count returned to within a normal range after resection of the liver tumor. To our knowledge, these observations have not been reported before for patients with FDC tumors.

FDC tumors have been considered to have a malignant potential $(7,9)$. In a review article dealing with 47 well-documented cases of FDC tumors (9), $28(59 \%)$ patients were alive without disease, 6 (13\%) were alive with recurrent disease or metastasis, and 7 (14\%) had died with recurrent disease at the time of last follow-up. Adverse clinical outcome was correlated with intraabdominal location, large tumor size (more than $6 \mathrm{~cm}$ ), high mitotic count (more than 5 per 10 high-power field), coagulative necrosis, and cellular atypia. On the basis of our experience and three previously reported cases (10-12), FDC tumors of the liver might not be as aggressive as the reported intraabdominal cases because local recurrence only occurred in one of the five cases over 1- to 5-year follow-ups. Although the tumor in Case 1 of our series was progressively growing in the absence of surgical resection, no metastases were found over a 3 -year period. Therefore, FDC tumors of the liver may be a low-grade malignancy.

The major differential diagnoses included Hodgkin's disease and inflammatory pseudotumor $(9,11)$. Because FDC tumor may contain some Reed-Sternberg-like cells, it may be confused with Hodgkin's disease, especially in needle biopsy specimens (11). It is also difficult to distinguish FDC tumor from inflammatory pseudotumor. In fact, inflammatory pseudotumor represents a family of lesions diverse in nature and etiology, including reparative lesions, infective lesions, myofibroblastic neoplasms, and FDC tumors (14). The diagnosis of FDC tumor should be based on the recognition of FDCs, which exhibit distinctive histologic features. However, a definite diagnosis requires confirmation with immunohistochemical studies. FDCs are immunoreactive with the antibodies CD21, CD35, CD23, R4/23, and KiM4 (9, 10, 14). Our cases were confirmed by immunoreactivity with CD21 and CD23. But they were unstained with CD35. The staining for CD35 is highly variable on formalinfixed and paraffin-embedded tissue, even with microwave pretreatment $(9,10)$. This experience has been documented. The staining for muscle-specific actin (HHF-35) was also positive in our cases. The finding has been described in some FDC tumors by Chan et al. (7). It should not lead to misdiagnose other mesenchymal tumors. The small lymphocytes in the background were found to be composed predominantly of $\mathrm{CD} 3(+)$ cells, among which CD8(+) cells outnumbered CD4 $(+)$ cells. The plasma cells in our study were a mixture of $\lambda(+)$ and $\kappa(+)$ light-chain cells. These results are consistent with those of previous reports (10-12).

EBV has been detected in FDC tumor previously. This is not surprising because CD21 is the EBV 
TABLE 2. Summary of Reported Cases of Follicular Dendritic Cell Tumors of the Liver

\begin{tabular}{|c|c|c|c|c|c|c|c|}
\hline Case & Authors (Citation No.) & Age/Sex & $\begin{array}{l}\text { Site/Size } \\
(\mathrm{cm})\end{array}$ & Symptoms & EBV & Outcome & Remarks \\
\hline 1 & Shek et al. (8) & $35 / \mathrm{F}$ & $\mathrm{R} / 20$ & $\begin{array}{l}\text { Epigastric discomfort, low- } \\
\text { grade fever, weight loss }\end{array}$ & + & Recurrent at $30 \mathrm{mo}$ & \\
\hline 2 & Selves et al. (9) & $68 / \mathrm{F}$ & $\mathrm{L} / 11$ & $\begin{array}{l}\text { Malaise, weight loss, mild } \\
\text { anemia }\end{array}$ & + & Alive and well at $2.5 \mathrm{y}$ & \\
\hline 3 & Shek et al. (10) & $37 / \mathrm{F}$ & $\mathrm{R} / 15$ & Malaise, weight loss & + & Alive and well at $2 \mathrm{y}$ & \\
\hline 4 & Chen et al. (this study) & $57 / \mathrm{F}$ & $\mathrm{L} / 9.5$ & Intermittent epigastralgia & + & Alive and well at $3 \mathrm{y}$ & $\begin{array}{l}\text { Leukocytoclastic } \\
\text { vasculitis }\end{array}$ \\
\hline 5 & Chen et al. (this study) & $51 / \mathrm{F}$ & $\mathrm{L} / 12$ & $\begin{array}{l}\text { Abdominal fullness, weight } \\
\text { loss }\end{array}$ & + & Alive and well at $1 \mathrm{y}$ & $\begin{array}{c}\text { Blood and tissue } \\
\text { eosinophilia }\end{array}$ \\
\hline
\end{tabular}

EBV, Epstein-Barr virus; F, female; R, right; L, left.

receptor. Approximately $12 \%$ of all reported cases of FDC tumors are associated with EBV (9). The association of FDC tumor with EBV seems to vary in different organs. FDC tumors of the liver, including the cases from Hong Kong and France, were all identified as being EBV related (10-12). The role of EBV nevertheless remains unclear in the pathogenesis of FDC tumors. Southern blot analysis demonstrated that it is a clonal proliferative disease $(10$, 11 ), indicating that the EBV infection occurred before the monoclonal proliferation of the neoplastic FDC. LMP-1 is an integral membrane protein containing 386 amino acids and is encoded by the BNLF gene (also called LMP-1 gene) of EBV (15-17). LMP-1 is considered to be a viral oncogene because of its capacity to transform rodent fibroblasts in vitro and render them tumorigenic in nude mice (18). LMP-1 also serves as a target for T-cell-mediated cytotoxicity (19). Any mutations in the LMP-1 gene that result in failure to be recognized by $\mathrm{T}$ cells would allow the LMP-1 variant to escape immunologically mediated elimination (20). DNA sequencing of the LMP-1 gene in hepatic FDC tumor reported by Selves et al. showed three point mutations in Exon 3 of the LMP-1 gene as compared with the standard sequence of the EBV strain B95-8. In our series, Case 2 had a 30-bp deletion in Exon 3 of the LMP-1 gene, which was different from that reported by Selves et al. In addition, six point mutations were also present in Exon 3. The significance of the 30-bp deletion and six point mutations of the LMP-1 gene remains unclear. The deletion strain is prevalent in Taiwan, is not restricted to nasopharyngeal carcinoma, and was also found in throat washings of healthy individuals (21). Therefore, the clinicopathologic significance of the 30-bp deletion of Exon 3 of the LMP-1 gene in FDC tumors warrants further investigation.

\section{REFERENCES}

1. Monda L, Warnke R, Rosai J. A primary lymph node malignancy with features suggestive of dendritic reticulum cell differentiation. A report of 4 cases. Am J Pathol 1986;122: 562-72.
2. Chan JKC, Tsang WYW, Ng CS, Tang SK, Yu HC, Lee AWM. Follicular dendritic cell tumors of the oral cavity. Am J Surg Pathol 1994;18:148-57.

3. Chan JKC, Tsang WYW, Ng CS. Follicular dendritic cell tumor and vascular neoplasm complicating hyaline-vascular Castleman's disease. Am J Surg Pathol 1994;18:517-25.

4. Hollowood K, Stamp G, Zouvani I, Fletcher CDM. Extranodal follicular dendritic cell sarcoma of the gastrointestinal tract: morphologic, immunohistochemical and ultrastructural analysis of two cases. Am J Clin Pathol 1995;103:90-7.

5. Nayler SJ, Verhaart MJS, Cooper K. Follicular dendritic cell tumor of the tonsil. Histopathology 1996;28:89-92.

6. Saiz AD, Chan O, Strauchen JA. Follicular dendritic cell tumor in Castleman's disease. A report of two cases. Int J Surg Pathol 1997;5:25-30.

7. Chan JKC, Fletcher CDM, Nayler SJ, Cooper K. Follicular dendritic cell sarcoma. Clinicopathologic analysis of 17 cases suggesting a malignant potential higher than currently recognized. Cancer 1997;79:294-313.

8. Perez-Ordonez B, Erlandson RA, Rosai J. Follicular dendritic cell tumor: report of 13 additional cases of a distinctive entity. Am J Surg Pathol 1996;20:944-55.

9. Perez-Ordonez B, Rosai J. Follicular dendritic cell tumor: review of the entity. Semin Diagn Pathol 1998;15:144-54.

10. Shek TWH, Ho FCS, Ng IOL, Chan ACL, Ma L, Srivastava G. Follicular dendritic cell tumor of the liver. Evidence for an Epstein-Barr virus-related clonal proliferation of follicular dendritic cells. Am J Surg Pathol 1996;20:313-24.

11. Selves J, Meggetto F, Brousset P, Voigt JJ, Pradere B, Grasset $\mathrm{D}$, et al. Inflammatory pseudotumor of the liver: evidence for follicular dendritic cell proliferation associated with clonal Epstein-Barr virus. Am J Surg Pathol 1996;20:747-53.

12. Shek TWH, Liu CL, Peh WCG, Fan ST, Ng IOL. Intraabdominal follicular dendritic cell tumour: a rare tumour in need of recognition. Histopathology 1998;33:465-70.

13. Knecht H, Bachmann E, Brousset P, Sandvej K, Nadal D, Bachmann F, et al. Deletions within the LMP 1 oncogene of Epstein-Barr virus are clustered in Hodgkin's disease and identical to those observed in nasopharyngeal carcinoma. Blood 1993;82:2937-42.

14. Chan JKC. Proliferative lesions of follicular dendritic cells: an overview, including a detailed account of follicular dendritic cell sarcoma, a neoplasm with many faces and uncommon etiologic associations Adv Anat Pathol 1997;4;387-411.

15. Bankier AT, Deininger PL, Satchwell SC, Baer R, Farrell PJ, Barrell BG. DNA sequence analysis of the EcoRI Dhet fragment of B95-8 Epstein-Barr virus containing the terminal repeat sequences. Mol Biol Med 1983;1:425-45.

16. Fennewald S, van Santen V, Kieff E. Nucleotide sequence of a mRNA transcribed in latent growth-transforming virus infection indicates that it may encode a membrane protein. J Virol 1984;51:411-9.

17. Hudson GS, Farrell PJ, Barrell BG. Two related but differentially expressed potential membrane protein encoded by the 
EcoRI Dhet region of Epstein-Barr virus B95-8. J Virol 1985; 53:528-35.

18. Wang D, Liebowitz D, Kieff E. An EBV membrane protein expressed in immortalized lymphocytes transforms established rodent cells. Cell 1985;43:831-40.

19. Murray RJ, Kurilla MG, Brooks MJ, Thomas WA, Rowe M, Kieff E, et al. Identification of target antigen for the human cytotoxic T cell response to Epstein-Barr virus (EBV). Implication for the immune control of EBV-positive malignancies. J Exp Med 1992;176:157-68.
20. Trivedi P, Hu LF, Chen F, Christensson B, Masucci MG, Klein $\mathrm{G}$, et al. Epstein-Barr virus (EBV)-encoded membrane protein LMP 1 from a nasopharyngeal carcinoma is nonimmunogenic in a murine model system, in contrast to a B-cell derived homologue. Euro J Cancer 1994;30A:84-8.

21. Chang TS, Su IJ, Chung PJ, Shu CH, Ng CK, Wu SJ, et al. Detection of an Epstein-Barr virus variant in T cell lymphoma tissues identical to the distinct strain observed in nasopharyngeal carcinoma in the Taiwanese population. Int J Cancer 1995;62:673-7. 